J. Perinat. Med.

3 (1975) 242

\title{
Individual correction of birth weight for parental stature with special reference to small-for-date and large-for-date infants
}

\author{
P. Lazar, J. Dreyfus, E. Papiernik-Berkhauer \\ Unité de Recherches Statistiques, Villejuif, GEPSP, Haguenau, \\ Faculté de Medecine, Université Paris-Sud
}

Received December 4, $1974 . \quad$ Accepted May 2, 1975.

The expected birth weight of infants is known to depend on several factors: Gestational age at birth, sex, mother's age, parity and smoking habits, parental stature etc. Two of these factors, sex and gestational age, are now commonly taken into account when one has to decide whether a baby is "too small" or "too big", at birth $[5,3]$, even if the utility of doing so is still controversial [8]. The usual name given to such babies (smallfor-date, large-for-date) is a reflection of this definition. One may question if it would not be useful to take into account in the same way other factors responsible for a notable part of the variance of birth weight, and several authors have suggested the use mother's weight and/or height for this purpose $[2,5]$. The object of the present paper is to discuss the a priori appropriateness of such a correction, enlarged to include father's weight and height contribution, and to give practical rules for its use. Special attention will be given to the variations in the pattern of correlations between parental weight and height and birth weight according to mother's age.

\section{Material and Methods}

The sample is constituted by all the births registred in the maternity hospital of Haguenau (a small town in eastern France) between February 1971 and June 1973. However if a woman had more than one pregnancy during this period, only the first one was considered, in order to avoid an overrepresentation of some women. The sample

\section{Curriculum vitae}

Philippe Lazar was born in 1936. He is engaged in epidemiological research, since 1960 , in the Statistical Research Unit of the National Institute of Health and Medical Research (INSERM, Paris, France). He works more particularly in the field of perinatality (spontaneous abortions, prematurity, etc.). $\mathrm{He}$ is also Professor of Biostatistics in the Institute of Statistics of the Universities of Paris.

is thus slightly impoverished in multiparous pregnancies. Twins were also excluded.

The total number of births recorded, during the period of observation, was 3325. It was possible to obtain reliable information on the gestational age at birth for 3222 cases, 1664 males and 1558 females. The weight before pregnancy and the height of the mother were known for 3000 cases; father's weight and height, usually obtained from the women questioned, were known for only 1667 cases, since this was not asked for at the beginning of the survey. We used the whole sample for all the calculations except for those requiring father's measurements.

The main statistical tool used is multiple regression analysis [9]. This method allows one to find which variables are significantly related to the variable to be predicted (i. e. birth weight), and also to calculate the coefficients that apply to each of these variables in order to get the best linear estimate of the predicted variable. These coef- 
ficients also allow a calculation of the individual quantitative "correction" to be applied to the birth weight in order to take into account the explanatory variables.

In order to strengthen the power of the statistical tests performed, birth weight was replaced by a "standardized birth weight" (SBW) obtained by :

i) subtracting from each birth weight the mean value observed for the same gestational age and sex

ii) adding to each of these deviations the overall birth weight mean (in order to get final numbers of the same order of magnitude as birth weights).

As the variance of the distribution was almost constant from one category of gestational age and sex to another, this simple standardization by a correction of the mean allowed us to treat all the data together.

\section{Results}

The population of birth we deal with is a usual one for a maternity hospital. The mean age of the mother is 26.4 years, with a standard deviation of 5.8 years; the mean age of the father is 28.6 years, with a standard deviation of 5.9 years. The sex-ratio at birth is also normal $107: 100$.

\subsection{Correlations between SBW and parental weight and height}

Tab. I gives the pattern of the coefficients of correlation between the following five variables: SBW, maternal and paternal weight and height. All the coefficients are significant at 0.001 , except for the correlations between SBW and paternal height (which is significant at the 0.05 level only) and between paternal height and maternal weight (which is not significant).

On the basis of such a pattern of correlations, it is possible to carry out a first multiple regression analysis, which yields the following coefficients to apply tp parental stature values: 10.5 mother's weight (in kilograms), 7.6 for mother's height (in centimeters), 4.3 for father's weight (in kilograms) and 0 for father's height (no proper significance). In practice this means, for the instance, that for each kilogram of deviation of the mother's weight from the average value of the sample $(58.8 \mathrm{~kg})$, the birth weight of the child should be corrected by 10.5 grams, etc.

But this first correction may be criticized for two reasons :

i) it is based on the above described pattern of correlations, which was established on the whole sample and then might only be an average one if the correlations were different in definite subcategories of mothers, and

ii) it makes no distinction between the "genetic" and "environmental" components of the parental weights though such a distinction might be essential, as will be discussed below.

2.2 Correlations between SBW and parental weight and height according to mother's age

Tab. II gives the coefficients of correlation for seven classes of maternal age. Except for father's height, which is consistently not significantly related to SBW, almost all the coefficients are significant.

Tab. III gives the variations of child and parents characteristics, for the same classes of age.

Tab. I. Coefficients of correlation between SBW and parental stature

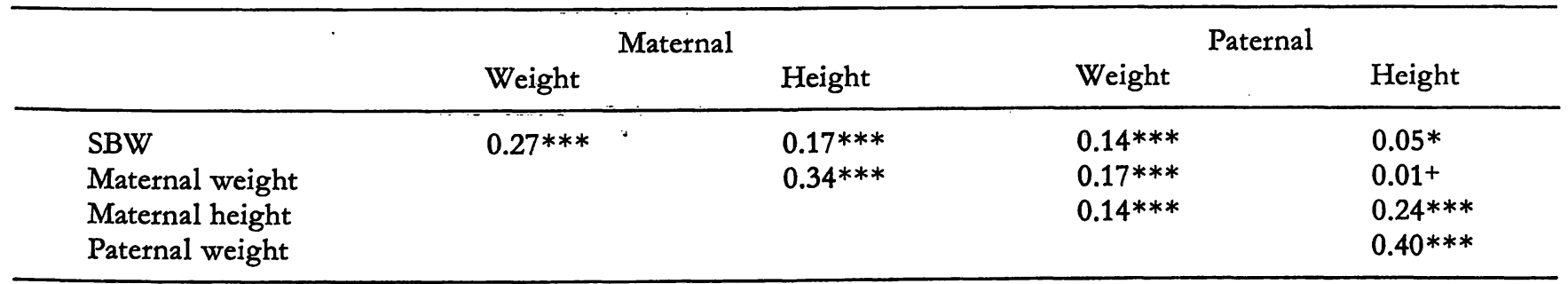

Legend: $+=$ Non significant; $* \mathrm{p}=0.05 ; * * \mathrm{p}=0.01 ; * * * \mathrm{p} \leqq 0.001$ 
Tab. II. Coefficient of correlation between SBW and parental stature according to maternal class of age $(*)$

\begin{tabular}{llllllll}
\hline Mother's age & $\leqq 17$ & $18-21$ & $22-21$ & $26-29$ & $30-33$ & , 34-37 & $\geqq 38$ \\
\hline Maternal weight & $0.17(67)$ & $0.21(707)$ & $0.27(987)$ & $0.28(580)$ & $0.32(368)$ & $0.17(246)$ & $0.25(147)$ \\
Maternal height & 0.17 & 0.17 & 0.16 & 0.19 & 0.21 & 0.20 & 0.18 \\
Paternal weight & $0.20(34)$ & $0.21(400)$ & $0.10(560)$ & $0.12(339)$ & $0.09(222)$ & $0.17(149)$ & $0.07(90)$ \\
Paternal height & -0.06 & 0.09 & 0.02 & 0.09 & -0.05 & 0.20 & 0.10 \\
\hline
\end{tabular}

$(*)=$ In brackets, the number of cases

Tab. III. Mean values of child and parents characteristics according to mothers' class of age

\begin{tabular}{lrrrrrrr}
\hline Mothers age & $\leqq 17$ & $18-21$ & $22-25$ & $26-29$ & $30-33$ & $34-37$ & $\geqq 38$ \\
\hline SBW (grams) & \multicolumn{1}{c}{3185} & 3264 & 3353 & 3393 & 3442 & 3419 & 3436 \\
Maternal weight (kg) & 55.1 & 55.7 & 57.5 & 58.4 & 59.8 & 62.1 & 64.4 \\
Maternal height (cm) & 159.6 & 161.6 & 161.6 & 161.5 & 161.8 & 161.1 & 160.0 \\
Paternal weight (kg) & 65.9 & 71.5 & 74.3 & 75.0 & 76.2 & 77.5 & 77.8 \\
Paternal height (cm) & 170.1 & 171.9 & 172.5 & 172.4 & 172.4 & 171.8 & 170.5 \\
\hline
\end{tabular}

For the first five classes of age, that is the main part of the sample, the following comments may be made:

i) SBW, maternal weight, and their correlation increase with mother's age. This is consistent with the hypothesis that birth weight depends both on "genetic" and "environmental" maternal factors such as nutritional factors: The more a mother is able to enlarge with age, the heavier her child becomes.

ii) SBW and paternal weight increase with age, but their correlation decreases. This was expected, since the genetic contribution of the father is progressively masked as he moves further away from his "genetic" weight and as the baby's weight depends more and more on mother's weight.

iii) The coefficients of correlation between SBW and mother's weight on the one hand, and father's weight on the other hand, start from the same value in the youngest age classes. This observations favours an almost purely genetic explanation of the observed correlation in these groups. Hence a correction calculated on the basis of these correlation may be considered as a good estimate of the genetic correction.

iii) The correlation between SBW and maternal height does not vary. One might have expected a slight decrease, because of the increase of the variance of SBW, except if SBW variations are themselves correlated to mother's height.

In the last two classes of age, that is after 34 years, the correlations do not follow the previous general trend. Other phenomena, related to mother's weight, such as a higher blood pressure, probably play a role. These factors imply the cessation of the increase of the average birth weight and a correlative decrease of SBW and mother's weight correlation.

\subsection{Birth weight correction calculated from parental stature at 20 years}

Tab. IV gives the coefficients to apply to parental stature values, obtained from a multiple regression analysis of data obtained from mother's aged, either taking into account parental height and weight, or parental weight only. An individual correction must be calculated on the basis of the deviations from the mean values of parental measurements in this group. Ideally for each older couple, the weights of both parents when they were about 20 years old should be known. If this information is lacking; it is possible to replace it by an estimate, substracting from the current weight the mean effect of age and, for mothers, of parity, obtained from a multiple regression analysis of all the dates. The reliability of such an estimate rests on the hypothesis of 
Tab. IV. Coefficients of correction and mean parental stature values calculated for mothers aged $18-21$ years

\begin{tabular}{llcccc}
\hline \multicolumn{1}{c}{ Mean value } & $\begin{array}{c}\text { Mother's } \\
\text { weight } \\
56.1\end{array}$ & $\begin{array}{c}\text { Mother's } \\
\text { height } \\
161.7\end{array}$ & $\begin{array}{c}\text { Father's } \\
\text { weight } \\
71.4\end{array}$ & $\begin{array}{c}\text { Father's } \\
\text { height } \\
172.3\end{array}$ \\
\hline $\begin{array}{l}\text { Coefficients to apply to the } \\
\text { deviations if taking into } \\
\text { account parental }\end{array}$ & $\begin{array}{l}\text { weights and } \\
\text { heights } \\
\text { weights only }\end{array}$ & 8,4 & 6.5 & 7.3 & 0.5 \\
\hline
\end{tabular}

absence of major cohort variations. According to this approximation, the current weight of the mothers should be reduced by 200 grams per year of age above twenty and by 900 grams per previous pregnancy. For the fathers the reduction would be of about $\mathbf{3 5 0}$ grams per year of age above twenty.

\section{Discussion}

Clearcut correlations have been established between birth weight and mother's height [1], weight [7], or weight-for-height [3]. From these relationships, several authors have attempted to correct birth weight taking into account maternal stature, either using tables [2] or charts [5]. However it is not possible to decide if, or how, any corrective factor should be used, independently of the further utilization of the corrected weight. The above mentioned stature corrections have often been successfully introduced in order to compare regions, ethnic groups etc. When used in order to improve individual diagnosis of small- or large-for-date infants, they have been found not to be entirely satisfactory [8]. This is not surprising. We have seen that our data supported the existence of two components of maternal weight that influence birth weight: One is genetic, the other is environmental, probably directly related to the "nutritional ability" of the mother. It would be an error in logic to correct birth weight for the latter if one wants to determine which are the underweight or overweight babies. A correction based on the current weight would introduce an overestimation of the number of small-for-dates and an underestimation of the number of large-for-dates.

The difficulty is naturally to find a quantitative method for the estimation of the legitimate ("genetic") correction. The one proposed in this paper is based on the observed inverse variations of the coefficients of correlation between birth weight and mother's and father's weight according to age, from the same value $(0.20)$ at about twenty years. These data are consistent with the hypothesis that, at this age, the correlation results mainly from genetic factors. One could have expected, in the same way, to find an identical correlation between birth weight and mother's height on the one hand and father's height on the other hand. Such is not the case : Tab. II shows that the coefficient of correlation between paternal height and birth weight is 0.09 in the 18-21 mother's class of age, against 0.17 for the coefficient between maternal height and birth weight. Only the second correlation is significant, even if the first one cannot be completely excluded.

Two reasons might explain the relatively low value of the paternal height-birth weight correlation: Either the correlation between parental height and birth weight is not essentially of genetic origin, or our knowledge of father's height obtained from wife's answers is too imprecise. The latter explanation is not likely, since there is no reason why knowledge of fathers height should be less accurate than knowledge of father's weight, and since the observed correlation between father's height and weight is rather higher than the same correlation for the mother (Tab. I). The former reason is then probably true and at least provisionally on the basis of our data, only the parental weights should be kept for the final correction (last line of Tab. IV).

This conclusion also raises the question of the interpretation of the correlation between maternal height and birth weight in non genetic terms : A possible explanation would call upon the "nutritional ability" of the mother towards her baby and towards herself during her own childhood. Socioeconomic factors could also interfere. 
Paternal weight correction appears then to be as important as the maternal one. This is not basically surprising, but it is naturally different from what we found and what is described in the literature [4] when the whole population is used to calculate the coefficients.

Parity has not been taken into account to establish the correction since the great majority of women of the 18-21 mother's class of age are primiparous or at least of low parity. But this correction can obviously be applied to any woman, whatever her parity may be, in so far as this correction is aimed at being a genetic one, that is independent from the gestational history.

As the definition of small-for-date or large-for-date is usually based only on the total weight of a baby, without any reference to other stature measurements, it must be pointed out that the proposed correction is only a birth weight correction.

\section{Summary}

The aim of the present paper is to determine how parental stature measurements should be used to "correct" birth weight in order to improve the diagnosis of small or big-for dateness. A first approach, based on the pattern of coefficients of correlation between maternal and paternal weight and height, and birth weight (Tab. I), may be criticized for two reasons: i) it does not take into account the possible variations of this pattern of correlations from one subcategory (for instance of age) of the sample to another and ii) it makes no difference between "genetic" and "environmental" components of parental influence on birth weight. A second approach takes into account the variations of parental stature measurements, of birth weight and of the pattern of correlations according to mother's age (Tabs. II and III). Briefly: The correlation between birth weight and mother's weight increases, the correlation between
Nevertheless, one may question if it would not be useful to go further and to take also into account information on the "quality" of the birth weight, and, more generally, to base a definition of smalland large-for-date on more than one stature measurement. It would be worth then to compare the prognostic value of all those corrected assessments of small-and large-for-date in terms of perinatal morbidity and mortality. Such work is in progress in our survey.

The increase of the correlation between birth weight and maternal weight with mother's age demonstrates that the ability of the mother to increase her own capacity to assimilate nutritional elements is parallel to her ability to bear a heavier baby. This observation may be useful in the problem of the prevention of small- or large-for-date deliveries resulting from maternal metabolic disorders.

birth weight and father's weight decreases when mother's age increases (except for mother's older than 34 ), and these coefficents have the same value in the youngest group (mothers less than 21). These observations are consistent with the hypothesis of the predominance of the "genetic" component in the youngest group, which leads to the establishment of the coefficients to apply to each parental stature measurement by means of a multiple regression analysis carried out on this only group (Tab. IV). For the whole population, the correction must finally be calculated using the weights of parents at 20 years (or, if unknown, an approximate value). The correction is about ten grams per kilogram of mother's and eight grams per kilogramm of father's weight deviations from the mean values of the population to which they belong.

Keywords: Birth weight, large-for-dates, maternal age, maternal height, maternal weight, paternal height, paternal weight, small-for-dates.

\section{Zusammenfassung:}

Individuelle Korrektur des Geburtsgewichtes auf Grund der Statur der Eltern und spezieller Berücksichtigung der tragzeitbezogenen Unter- bzw. Übergewichtigkeit.

Ziel der vorliegenden Arbeit ist, aufzuzeigen, wie die Körpermaße der beiden Eltern verwendet werden sollten zur Korrektur des Geburtsgewichtes, um die Diagnosestellung der tragzeitbezogenen Unter- oder Übergewichtigkeit zu verbessern. Eine erste Analyse, die sich auf das Muster von Korrelationskoeffizienten zwischen müttrelichem und väterlichem Gewicht, bzw. der Körpergröße beider Eltern einerseits, und dem Geburtsgewicht (Tab. I) andererseits stützt, kann aus 2 Gründen kritisiert werden.
1. Sie berücksichtigt nicht die mögliche Streubreite dieser Korrelationen, welch erstere bedingt ist. durch Subkategorien (wie z. B. das Alter) dieser Stichprobe und der nächsten. Und

2. unterscheidet diese Analyse nicht zwischen den ,genetischen" und „unweltbedingten“ Anteilen des elterlichen Einflußes auf das Geburtsgewicht.

Ein zweiter Versuch berücksichtigt die Streubreite der elterlichen Körpermaße, des Geburtsgewichtes und die Streuung der Korrelationen, welche durch das Alter der Mutter (Tab. II und III) bedingt ist. Kurz gesagt: mit zunehmendem Alter der Mutter (ausgenommen Mütter über 34 Jahren) nimmt die Korrelation zwischen Ge- 
burtsgewicht und mütterlichem Körpergewicht $z u$, jene zwischen Geburtsgewicht und Körpergewicht des Vaters jedoch ab; die Koeffizienten haben denselben numerischen Wert in der Gruppe mit den jüngsten Probandinnen (Alter der Mutter weniger als 21 Jahre). Diese Beobachtungen sind im Einklang mit der Hypothese der Prädominanz des "genetischen" Anteiles in der Gruppe mit den jüngsten Probandinnen; dieses führt mit Hilfe der multiplen Regressionsanalyse, die nur in dieser Gruppe durchgeführt warde (Tab. IV), zur Festlegung dieser Koeffizienten, welche nun bei allen beliebigen Körpermaßen der Eltern zur Anwendung kommen. Für das gesamte Kollektiv muß die Korrektur schließlich berechnet werden unter Einbeziehung des Gewichtes der Eltern in ihrem 20. Lebensjahr, oder, falls dies unbekannt ist, unter Verwendung eines approximativen Wertes. Die Korrektur bcträgt ungefähr $10 \mathrm{~g} / \mathrm{kg}$ der Abweichung des mütterlichen und $8 \mathrm{~g} / \mathrm{kg}$ der Abweiweichung des väterlichen Gewichtes von dem mittleren Wert der Population, zu welcher sic gehören.

Schlüsselwörter: Geburtsgewicht, Gewicht des Vaters, Körpergröße des Vaters, mütterliches Alter, mütterliches Gewicht, mütterliche Größe, terminbezogene Übergewichtigkeit, terminbezogene Untergewichtigkeit.

\section{Résumé}

Correction individuelle des poids de naissance en fonction des variations caractéristiques staturo pondérales des parents, avec étude particulière des enfants hypotrophiques et hypertrophiques.

L'object du présent article est de déterminer comment les mesures de stature pondérale devraient être utilisées pour "corriger» le poids de naissance en vue d'une amélioration du diagnostic d'hypotrophie et d'hypertrophie foetales. Une première approche, fondée sur l'ensemble des coefficient de corrélation entre les poids et tailles parentaux et le poids de naissance (Tab. I), peut-être critiquée pour deux raisons: i) elle ne prend pas en compte les variations possibles de cet ensemble de corrélations d'une sous catégorie (par exemple d'âge) de l'échantillon à l'autre et ii) elle n'établit aucune différence entre les composantes «génétique» et «environnementale» de l'influence parentale sur le poids de naissance, Une seconde approche prend en compte les variations des mesures de stature parentale, de poids de naissance et du tableau de leurs corrélations en fonction de l'âge de la mère (Tab. II et III). Brièvement: la corrélation entre le poids de naissance et le poids de la mère croît, la corrélation entre le poids de naissance et le poids du père décroît quand l'âge de la mère croît (à l'exception des mères de plus de 34 ans) et ces coefficients ont la même valeur dans le groupe le plus jeune (mères de moins de 21 ans). Ces observations sont cohérentes avec l'hypothèse d'une prédominance de la composante génétique dans le groupe le plus jeune, ce qui conduit à établir les coefficients à appliquer à chaque mesure de stature parentale par une regression multiple effectuée sur ce seul groupe (Tab. IV). Pour l'ensemble de la population, la correction doit finalement être calculée en utilisant les poids des parents à 20 ans (ou, s'ils sont inconnus, une valeur approchée). Une telle correction est a priori meilleure que celle qui serait fondée sur le poids habituel puisque un accroissement du poids maternal avec l'âge entraine un accroissement réel du poids de l'enfant, et qu'un accroissement de poids du père ne modifie évidement pas sa contribution génétique à ce poids. La correction est d'environ dix grammes par kilogramme d'écart de la mère et huit grammes par kilogramme d'écart du père au poids moyen de la population à laquelle ils appartiennent.

Mots-clés: Age maternel, hypertrophie foetale, hypotrophie foetale, poids de la mère, poids de naissance, poids du père, taille de la mère, taille du père.

\section{Bibliography}

[1] Butler, N. R., E. D. Alberman: Perinatal problems. Livingstone, Edinburgh - London 1969

[2] Goujard, J., M. Kaminski, C. Rumeau-Rouquette: Moyenne pondérale et age gestationnel en relation avec quelques caractéristiques maternelles. Arch. Franç. de Pédiatrie 30 (1973) 341

[3] Lubchenco, L. O., C. Hansman, M. Dressler, E. BOYD: Intrauterine-growth as estimated from liveborn birth-weight data at 24 to 42 weeks of gestation. Pediatrics 32 (1962) 793

[4] Ounsted, M., C. Ounsted: On fetal growth rate. Heinemann, London 1973

[5] TÁnner, J. M., A. M. Thomson, : Standards for birthweight at gestation periods from 32 to 42 weeks, allow- ing for maternal height and weight. Arch. Dis. Childh. 45 (1970) 566

[6] Thomson, A. M., W. Z. Billewicz: The assessment of fetal growth. Obstet. Gynaec. Brit. Cwlth. 75 (1968) 903

[7] Timonen, S., U. Uotmla, P. Kuusisto, P. Vara, O. Lokkr: Ann. Chir. Gynaec. Fenn. 55 (1966) 196

[8] Rantakallio, P.: Characteristics of the mother and child in groups based on different concepts of low birth weight. Ann. Chir. Gynneac. Fenn. 62 (1973) 19, Suppl. 184.

[9] SEAL, H. : Multivariate statistical analysis for biologists. Methuen, London 1964
Dr. P. Lazar

Unité de Recherches Stat. 16 bis, ave. P. V. Couturier 94800 Villejuif/France 